\title{
PECULIARITIES OF THE EMPLOYEES RECRUITMENTS BY RURAL EMPLOYERS: THE CASE OF LATVIA
}

\author{
Liga Rasnaca ${ }^{1}$
}

Received 3 October 2011; Accepted 23 March 2012

\begin{abstract}
The main issues of this study are the peculiarities of recruitment of employees by rural employers and the differences between recruitment strategies in urban and rural areas. The author is interested in the description of these differences both by the objective and subjective factors. Theoretical considerations are based on Manuel Castells' theory of "space of flows" as well as on the theoretical interpretation of the "flexibility" concept in labour market relations. The empirical results include quantitative and qualitative analyses of survey and interviews of Latvian employers. There are significant differences in recruitment ways and working agreement forms offered by employers in rural and urban areas.
\end{abstract}

Key words: flexibility, rural employers, employee recruitment.

Rezumējums: Galvenais pētījumā apskatītais jautājums ir darba devēju darbinieku meklēšanas specifika laukos, kā arī atšķirības stratēǵijās, kādas darbinieku meklēšanai un pieñemšanai izmanto darba devēji laukos un pilsētās. Autori interesē šo stratēǵiju atšķirīibu izskaidrojums, ievērojot kā objektīvos, tā subjektīvos faktorus. Pētījumā ietvertie teorētiskie apsvērumi pamatoti ar Manuela Kastela "plūsmu telpas" teoriju, kā arī darba tirgus attiecību "elastības" jēdziena teorētisko interpretāciju. Empīriskie rezultāti ietver kvantitatīvo un kvalitatīvo datu analīzi, kas iegūti Latvijas darba devēju aptaujā un intervijās. Pētījumā konstatētas nozīmīgas atšķirības darba līgumu piedāvājumā un darbinieku meklēšanas veidos starp lauku un pilsētu darba devējiem.

Atslēgas vārdi: elastība, lauku darba devēji, darbinieku meklēšana

\section{Introduction}

The article focuses mainly on the agents of labour market (employers and employees) in the context of formation of labour market relations, e.g. employment agreement and various ways how to recruit employees. The labour market is an area where employees are exchanging their working force for money, status and other benefits acquired by paid work (Kalleberg, Sorensen, 1979). The concept encompasses institutes and practices that determine

\footnotetext{
1 Liga Rasnaca, PhD (Dr. sc. soc.), Latvia University of Agriculture, Faculty of Social Sciences, e-mail: liga.rasnaca@llu.Iv
} 
the processes of change and reception of services between employees and employers. The representatives of economic sociology have assumed that labour market is not a real market (universal, impersonal mechanism which is not taking into account such aspects as gender, age, colour and ethnical background of agents) (Streeck, 2005; Swedberg, 2005). Similar approach could be observed also by economists, for example, representatives of institutional economic (Bromley, 1989; Douglas, 1990).

The core and periphery of the labour market could be regarded in both: the geographical context and as the social segmentation (Lamote, Zubirirey, 2008). Various segments of rural and urban areas differ in the level of security, salary, demands for qualification etc. The division in "rural" and "urban" areas results in different interpretations of "rural and urban labour market's" identity (Copus, Hall, et al., 2006). Urban and rural regional differences could be interpreted as a long-term result of social inequality in remote rural areas (far from central urban region, difficult to access) (Bird et al., 2003). When determining the "urban" and "rural" areas, the author as the basis uses the recommendations of the Organisation for Economic Development and Cooperation (population density, distribution of population, and the size of cities). In accordance with this classification only the Latvian capital Riga and its surroundings are predominantly urban regions; whereas, the rest of the country is predominantly rural (Latvia. Human Development Report 2006/2007, 2007).

The aim of study is to find out peculiarities of the recruitment of employees by rural employers in Latvia. The main attention is paid to finding out the ways how employees are recruited in rural areas, as well as how these ways differ from recruiting in urban areas. The main tasks of the article are:

1) to construct theoretical frame for the analyses of regional differences in recruitment of employees by rural employers;

2) to analyse secondary data of employers' survey in order to find out regional differences in recruitment of employees;

3) to identify rural employers' justification of chosen employees recruitment strategy.

The theoretical considerations are based on Spanish descendant American sociologist Manuel Castells'(Manuel Castells) ideas about space as organizational form in network society and flexibility in labour market relations. The article includes theoretical background, methodological approach, results and discussion and conclusions.

\section{Theoretical background}

The research has been based on the Castells' concepts of the "space of flows" and "advanced services". The author's deep investigative interest in labour market relations in rural areas is based on two main reasons. First, the author is interested how the labour market relations in rural areas emerge. It seems necessary to find out, if they are characterised by similar tendencies to those described by the authors of macro theories (Castells) at the end of the $20^{\text {th }}$ century and specific labour market medium level theories. It is important to find out, if the labour market relations in rural areas of Latvia are characterised by similar or different tendencies as those in Riga and major towns. Second, the author looks into how the adaptation to the social and technological transformations of the $21^{\text {st }}$ century occurs in the labour market relations, especially recruitment of employees in rural areas.

The author's conceptual approach manifests itself in the appraisal of the advantages of Castells' space of flows (spread of advanced services) theory for the analysis of the differences in labour market relations of rural areas in Latvia. The author relates the advantages of Castells' space of flows theory with the fact that this theory allows to integrate material and social elements in the study of labour market relations in different types of settlement (rural/urban). Castells' terms of space of flows and advanced services allow the justification of social differences due to the place of settlement, unequal distribution of services, and creation and continuity of labour relations. Castells' theory stressed the meaning of informational and global economy processes organized around command and control centres, able to coordinate, manage and intertwined activities of economic networks. Space is not a reflection, but expression of society and spatial 
forms that are formed by the dynamics of social structure, material support for social practices (Castells, 2000). Castells understands flows as a three layer system: material support (for example, roads, ICT (informational communication technologies), transportation, etc.); nods of network: hierarchically organized spatial functional structure (social, cultural, administrative centres, communication hubs playing a role of coordination, etc. and spatial organization of managerial elite). Some places may be switched off the networks, their disconnection resulting in instant decline and social deterioration (Castells, 2000). The weak capacity of social power so could be expressed in weak infrastructure, information networks and organizational forms. ICT are integral part of space of flows and Castells represents scientists who accentuated revolution of skills and knowledge in labour market. As the result of complex action of space of flows elements remote places, segments of labour market in rural areas could participate in global labour market according with linkage to global flows.

Advanced services included finance, insurance, real estate, consulting, legal services, informational gathering and management of informational systems, research and development, scientific innovation and advertising (Castells, 2000). Availability of advanced services is also necessary for investments and development in rural areas. Advanced services promote possibilities for economic activities of rural employers, possibilities for linkages to global space of flows. Growing internationalization of economic activities made regions more dependent on space of flows. The influence of space of flows could be as well positive as negative to rural areas labour market.

Terry Marsden, professor at the Scottish University of Aberdeen, researcher of rural development, divides three possible variations of development of European rural areas: agriindustrial, post-productivist and sustainable rural development models. Marsden's model of sustainable rural development is close to Castells' theory of space of flows, underlining the influence of people (social capital), financial capital, and knowledge (human capital) on labour market relations in rural areas. There is a lack of protection mechanisms in rural areas against dangerous influence of space of flows, which do not allow maintenance of the local labour market. The sustainable model of rural development includes co-operation between urban and rural areas as a prerequisite for the long term functioning of rural labour market (Marsden, Smith, 2005). Labour market relations can only be created, if new labour market processes are happening (e.g. establishing of new employers, need for employees of a different qualification, knowledge and skills, change of the number of employees), which is the main reason why the author emphasizes that in rural areas the access to the space of flows is essential for the existence of labour market relations.

In order to deepen the analysis of labour market relationships the author uses the concept of flexibility, attributing those manifestations of flexibility in labour market relations that enable to talk about the expressions of post-Fordism and neo-Fordism in the relations between employers and employees. In order to analyse the flexibility of labour market relations the author has drafted a conceptual model, using the concept of flexibility myth by Harriett Bradley, researcher of gender and work sociology at the University of Bristol (Bradley et al., 2004). Bradley defends the thesis that rejects the statement of post-Fordism about the general revolution of knowledge skills in labour market relations. First, Breadly admits that the revolution of skills is attributed to the development of the service sector and the relative and absolute increase in the number of employers and employees in this sector in the post-industrial period, but, secondly, she indicates to the changes in the structure of the service industry, where the fastest growing industries are fast food and telecommunication centres. Bradley rather supports neo-Fordism conception about intensification and standardisation of work (Handel, 2003) than Castells' statement about the development of knowledge and information capable labour market relations in which educated and specific knowledge possessing employees are valued high. Changes in the labour market relations not always mean demand for higher level of education, knowledge and skills. In small towns and rural territories there are limited possibilities to develop fast growing service sector industries: fast food and telecommunication centres. The first lack clients but the second require safe connections and well-developed infrastructure; therefore, the offer of work places stays very limited also during the periods of growth. 
Flexibility means adaptation and diversity in market economy; at the same time, the perception of it differs accordingly to its localization in labour market system (employee, employer or government etc.).

The changes in labour market relations in rural areas cannot be considered separately from their previous historical development, because the opportunities of the present moment emerge from the configuration of political, economic, social and cultural elements developed in the previous periods. The progress of the labour market relations is explained by interaction of the endogenous and externally stimulating - exogenous development factors (Kostiainen, Sotarauta, 2003; Majerova, 2009). Global changes (e.g. employer and employee mobility, information flows) and the development of national economy are exogenous factors. Internal (endogenous) factors, that are not sometimes considered, are the significance of local social, as well as innovative networks and structures (Amin, Thrift, 1995). As the most important features of rural territories author evaluates the density of population and the distance to urban centres. In the case of Latvia that indicates limited representation of industries, limited work places for employees and the limited possibilities for employers. Similar as it was in Finland in the 90-ies of the $20^{\text {th }}$ century, in Latvia national level also prevails in the economy development policy; this is approved by the unclear status of regions, unequal territorial division, uncertainty of division of the cities, etc. Therefore, analysing problems of labour market relations in rural territories and small towns of Latvia, the common tendencies in the country's labour market and the regional policy should be observed.

In the understanding of labour market relations, space of a certain territorial unit is not the only factor affecting labour market relations but also a phenomenon that represents different labour market relations, and cultural and social characteristics (Rasnaca, 2010). Socio-spatial perspective, similarly to Castells' "space of flows" conception and Polish descendent English sociologist of culture Zygmunt Bauman's "non-place" notions, enables to integrate characteristics of social and material territorial units and creates a socio-spatial unity (Gottdiener, Hutchinson, 2006). Bauman's „non-place” and „stranger” are categories expressing global transformations in culture from one side and precautionary, distrustful attention to new incomers in some setting (for example, new, different employers, employees in rural areas) (Bauman, 2001). Sociospatial perspective allows analysing the impact of global flows on local labour market processes as a whole complex, e.g. the use of ICT, the assessment of the knowledge of foreign languages, etc.

When determining settlement areas of the cities and countryside, the author basis on the recommendations of the Organisation for Economic Development and Cooperation. The researchers conclusions regarding rural territories as different socio-spatial units (Van der Ploeg and Terry Marsden) enable the author to substantiate the application of the space of flows theory to the analysis of labour market relations in rural areas, where the threat of global risks are more expressed due to the remoteness of the territory and problems of infrastructure's availability. Therefore, the adjustment of labour market agents and flexibility of relations is even more necessary in rural territories and small towns to ensure the mere existence of rural settlement places and labour market relations.

Flexibility of the labour market in the EU countries has been an issue of social and economic development for at least the last three decades. Flexibility means survival in the constantly changing environment which requires adjustment; its perception differs depending on the position of labour market agent in the labour market. Flexibility is referred to both the length of work and the contract, as well as on the entrance into the labour market and leaving of it (Vander Steene et.al. 2008, Edgell 2006). The concept of flexibility is used when describing particular labour market agents and their mutual relationships. The author analyses flexibility of labour market relations when entering the market and maintaining the labour market relations.

The "flexibility" is a concept that may denote particular material changes and/or employer and employee strategies relating labour market. Flexibility is associated with the ability to survive in the global economics. Both the employer and the employee can be flexible, versatile, fastthinking, and ready to any changes. However, an inflexible employer or employee is hidebounded, bureaucratic, and resistant to change. The most frequently mentioned flexibility 
dimensions in the characteristics of employers are functional flexibility, numerical flexibility and external flexibility. Flexible employer and employee relationships can be characterised through the core and the peripheral part of the employer's employed staff (Strangleman, Warrren, 2008; Ghezzi, Mingione, 2007; Akiyoshi, 2003). Functional flexibility could be related to employees' recruitment, but external flexibility means variety of formal work conditions, including form of working agreement (Gouliquer 2000).

The flexibility can consolidate the employers and the employees, their relationships, by supplementing their skills and knowledge and by levelling the organisational hierarchy. It can also be understood as a phenomenon that deteriorates the employee's positions and does not solve the employer's problems; this turns into labour intensification and routinisation and formalisation of tasks. The ability to adjust is related to the notion of labour market relations flexibility or lack of it.

First, development of the labour market's regional differences is influenced by the space of flows because infrastructure, organisation of the information, and the transition and location of the management structure does not provide balanced labour market relations in the regional units. Second, the regions, particular environments, and residential areas are characterised by differences in their invariability, flexibility, energy and continuity. The concept of flexibility is connected to particular understanding of historical or theoretical labour market relations: mainly regarded to the adaptation problems of labour market agents and relations.

The adaptation is the answer to the challenges on different levels of global, national or local scale; it means new initiatives in labour market and the inclusion of social differences in the process of changing labour market. The issue of job search differences in remote rural areas has been investigated from distinct positions: from viewpoint of employers, employees and mediators in labour market (for example, employment agencies, and local governments). Interesting approach targeted to employment policy development has been taken up by Scottish researcher from Edinburgh Employment Institute Colin Lindsay. His study is devoted to employees' job search strategies in remote rural and peri-urban areas. Lindsay tested different job search ways, especially concentrated on informal search methods using social networks. Informal methods had also been identified in other previously done studies (Hodge et al., 2002; Lindsay et al.2003) and "pathways to work". Lindsay points out peculiarity in using social networks, especially informal ones in job search strategies by persons with different education level and living place. Lindsay recognizes specific difficulties for job seekers in remote rural areas. Author of current paper is investigating how employers in different regional units (including rural areas) use different ways looking for employees, are there differences between employers' and employees option and how employers justify their choice.

\section{Methodological approach}

Using the described conceptual model, the author has developed a four dimension consolidated index of flexibility of labour market relations by which it is possible to measure the flexibility in labour market relationships. Consolidated flexibility index includes four dimensions: recruitment, attachment, attitude towards employees of different social groups, and evaluation. Current study is devoted to the analysis of employees' recruitment flexibility dimension.

The methodology included quantitative and qualitative approach.

Quantitative analysis is based on two surveys:

1) Employers' survey of $2007, N=6,066$;

2) Population survey of $2011, \mathrm{~N}=1,009$.

The qualitative data are based on employers interviews conducted from 2006 till 2011, N=60.

The author analyses labour market relations by using secondary data from the survey "Specific problems of Latvia and its regions' labour market" (2007; $\mathrm{N}=6066)$ (Latvijas un tās regionu....,2007). The analysis is carried out from sociological perspective by using secondary data analysis and methods of mathematical statistics. The main focus of the research is to 
clarify regional differences in the employees' recruitment. The concept of flexibility in labour market relations is used in order to determine urban/rural differences in labour market relations.

The population survey 2011 shows popularity of different job search methods among employees and job seekers.

The employers included in the sample represent private and public sectors; different territorial units; planning regions, Riga (the capital city), major towns, other (small) towns and rural territories, as well as the employers with different number of employees. The variation of the number of employees comprises micro enterprises (2 to 9 employees), small enterprises (10 to 49 employees), medium-size enterprises (50 to 249 employees), and large enterprises (more than 250 employees). The representation of the sample units in the regional units in total corresponds to the proportion indicated in the statistical data; in some cases it has been corrected by weighting procedures according to the belongingness to the region, type of the settlement area, size of the enterprise/offices, and the sector. Data reliability and validity is ensured both by the sample size and by the applied weighting procedure. The sample comprises the necessary number of units for statistical analysis in the regions, as well as in different types of residential areas, groups of enterprises of different size and sectors.

The definition of the employer corresponds to the employer definition used by the Central Statistics Bureau according to the EU Eurostat requirements (EU statistics, CSB Latvia, 2011).

The measurable variables in the study: correspondence of the employee and employer relationships to the external flexibility (type of the work contract, existence of a collective agreement) in the different regional spatial units; internal and interpretive flexibility (types of employee recruitment, employers' opinion about employees' recruitment ways and their evaluation).

The author analyses secondary data from the employers' survey of 2007 in Latvia's regions. Two dimensions of flexibility have been analysed in current study.

1) Preference of employment agreement as element of external flexibility;

2) Ways of employees' recruitment (functional flexibility).

The main method used for data analyses is the cross tabulation and evaluation with Chi-square test, factor analyses and the index. Exploratory factor analyses type is Principal Components analyses (Varimax; significance $>0.4$; Cronbach's Alpha $=0.783$ ), The peculiarities of recruitment patterns used by rural employers are according to the answers to three questions: ways used looking for employees; stability of employer; forms of employment agreement used in rural/urban areas.

Qualitative interviews included wider description of recruitment peculiarities by rural employers from public and private sector.

\section{Results and discussion}

The survey starts with the analyses of the statistics regarding fields of industry in rural/urban areas, then by looking through data of population survey about most popular ways how employees are looking for new job; finally, there follows a more detailed discussion of employers' survey and, at the very end, the results of qualitative interviews are interpreted.

The statistic data show evident differences of the division of industries in rural and urban areas (Fig.1).

The number of occupied work places has dropped in all fields of economic activity included in the statistical data by NACE 2 after the year of 2007 . Only in three fields the situation has not become worse: finance and insurance $(K)$, the provision of professional, scientific and technical services (M), and in the operations of administrative and attendance services. These are the fields of advanced services demanding workforce that has special qualification and knowledge. All together, this can be described as a movement towards post-industrial labour relations with the features of post-Fordism. 


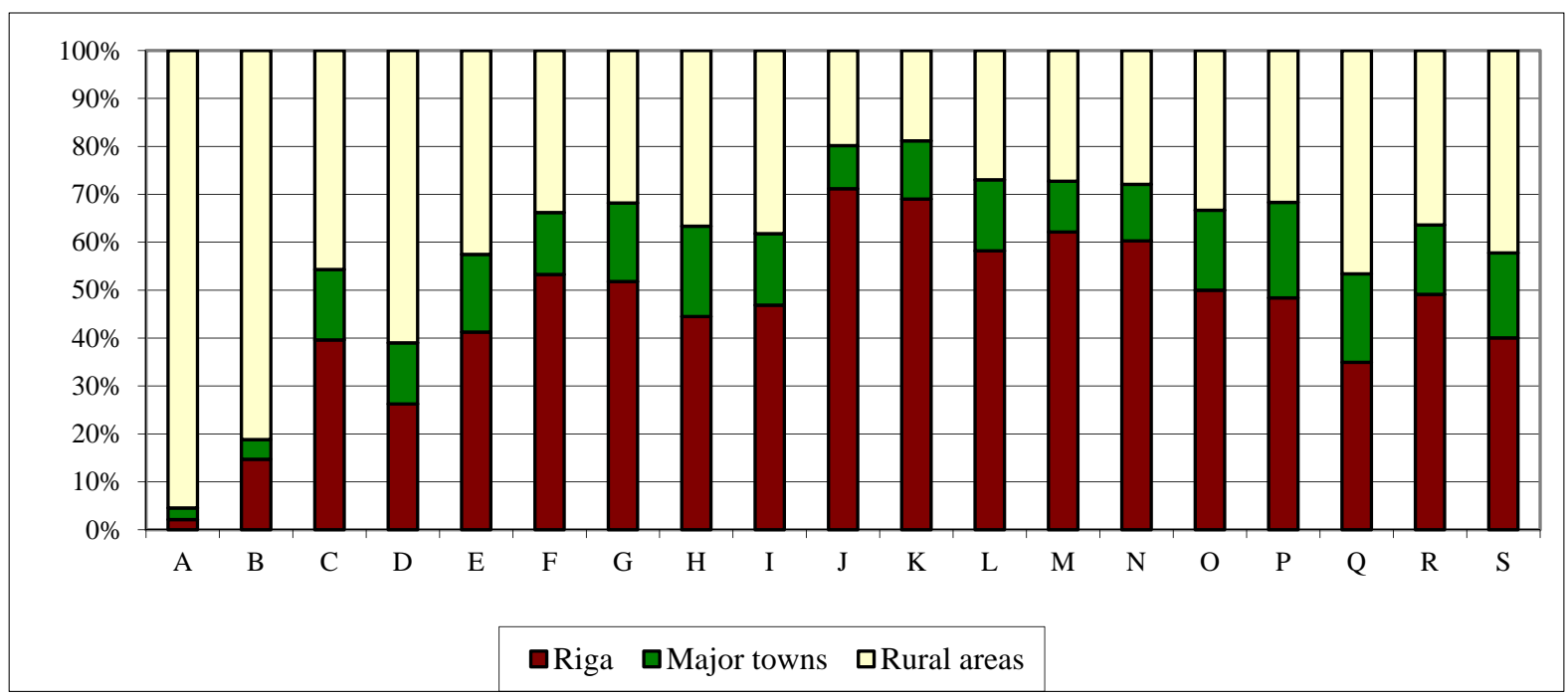

Fig 1. Economically active units of different branches in different types of settlement.

Source: The author's made according to the information from Latvia Central Statistics Board., Retrieved: 01.08.2011., http://data.csb.gov.Iv.

Fields of economic activity according to main industries. A - Agriculture, forestry, fisheries, B - Mining industry, C Manufacturing industry, D - Electricity, gas supply, heat supply, E - Water supply, waste utilization, F - Construction, G - Wholesale trade, retail trade, $\mathrm{H}$ - Transport and logistics, I - Hospitality services, J - Information and communication services, $\mathrm{K}$ - Finance and insurance, $\mathrm{L}$ - Real estate, $\mathrm{M}$ - Professional, scientific and technical services, $\mathrm{N}$ - Administrative services, $\mathrm{O}$ - State administration and defence, social insurance, $\mathrm{P}-$, education, $\mathrm{Q}-$ Health protection, $\mathrm{R}-$ Art, entertainment, recreation, $\mathrm{S}$ - Other services.

The primary fields (agriculture, forestry and the fishing industry), as well as some infrastructural fields - the power industry and the supply and delivery of gas and heat - are branches that most frequently operate in rural areas. In all other fields the number of economically active units in rural areas is smaller than in Riga or major towns even though the number of inhabitants is approximately equal in both groups of population (the percentage of population in all small towns and rural areas is $51 \%$ and the major towns and cities - 49\%) (Number of inhabitants, CSB, 2010).

The fields of economic activity least represented in rural areas are information technology and communication services $(\mathrm{J})$, financial and insurance operations $(\mathrm{K})$, professional, scientific and technical services (M), and administrative and caring services $(N)$. In comparison, Riga has a relatively high activity in these fields. These four mentioned types of services are mentioned by Castells as the advanced services, which are also the prerequisites for the access to the global space of flows and the post-industrial economic growth. In rural areas there is a lack of not only the mentioned services and their availability but also a lack of the work places for highly skilled workers, who could work to provide such services; accordingly, they do not have possibilities to work and live in the countryside. The mentioned fields are a perspective opportunity for potential economic activity in rural areas.

In absolute numbers the fields most represented in Riga (12,419 enterprises), major towns $(3,926)$ and in second place represented in rural areas $(7,622)$ are wholesale, retail, and car and motorcycle maintenance. The second most represented field of economic in Riga $(6,943$ enterprises $)$ and major towns $(1,769)$ is the real estate deals; while in the rural areas the first place goes to agriculture (29,961 enterprises), and in the third place is the manufacturing industry $(3,435)$, that most commonly means wood-processing.

The results of population survey 2011 show that the most popular way how inhabitants of Latvia are looking for work is the use of informal social networks (e.g. family members, relatives, friends and neighbours). There are no significant differences in the use of social networks between rural and urban population (seeking employment). The difference between rural and urban population is in the use of services of the Employment State Agency in search for a job. The rural job seekers are ready to use these services more often. (Chi-square < 0.05 ). Researcher of Employment Research Institute Colin Lindsay emphasizes role of informal social 
networks for rural job seekers, but admit also important role of Employment Agencies for local employers (Lindsay, et al., 2005).

\begin{tabular}{|l|c|c|c|c|c|}
\hline $\begin{array}{l}\text { Number of } \\
\text { employees }\end{array}$ & $\mathbf{2 - 9}$ & $\mathbf{1 0 - 4 9}$ & $\mathbf{5 0 - 2 4 9}$ & $\mathbf{2 5 0}$ and more & Total \\
\hline Riga & 48 & 29 & 17 & 6 & 100 \\
\hline Major towns & 62 & 25 & 10 & 3 & 100 \\
\hline Small towns & 59 & 29 & 11 & 1 & 100 \\
\hline Rural areas & 64 & 28 & 8 & 0 & 100 \\
\hline
\end{tabular}

$T a b$ 1. Number of employees in enterprise/organization in different types of settlement (\%), $N=6066$. Source: the authors' own study based on secondary data analyses of employers' survey from "Specific problems of Labour Market in Latvia and its' regions", 2007.

The number of employers size groups (Table 1) differ statistically significantly (Chi-square $<0.05$ ) in rural areas (including small towns) in comparison to urban areas (capital city Riga and major towns). There are less medium size employers and very few large ones. Lambd's indicator points to statistically significant associative connections between the size of enterprise and rural/urban area.

Therefore, the percentage of micro enterprises/offices is lower in Riga (48\%), but in the remaining territorial units it makes up to $59-64 \%$.

For more generalized analysis the author introduced the Recruitment Flexibility Index (table 2). According to quantitative results the most common ways how employers are looking for employees are recommendations of friends, relatives and acquaintances, and then follow advertisements in the mass media and on the Internet. These results contradict to ones presented by Lindsay study (2005) where author specially accentuated the use of Employment services.

\begin{tabular}{|l|c|c|}
\hline $\begin{array}{l}\text { Variables included in the Employees' Recruitment Flexibility } \\
\text { Index }\end{array}$ & Index & $\begin{array}{c}\text { Frequencies } \\
\text { ("always" or } \\
\text { "sometime") \% }\end{array}$ \\
\hline Announcement of competition for a vacancy & 0.34 & 33.3 \\
\hline $\begin{array}{l}\text { Workers are searched for according to the recommendation of } \\
\text { relatives, friends and acquaintances }\end{array}$ & 0.56 & 78.6 \\
\hline $\begin{array}{l}\text { Workers with necessary qualification are invited from other } \\
\text { enterprises }\end{array}$ & 0.26 & 43.3 \\
\hline Advertisements in the press, TV, radio & 0.37 & 52.4 \\
\hline Advertisements on the Internet & 0.22 & 31.8 \\
\hline Services of the Employment State agency & 0.23 & 35.8 \\
\hline Services of the personnel selection organizations & 0.04 & 7.7 \\
\hline
\end{tabular}

Tab 2. Structure of Employees' Recruitment Flexibility Index. Source: the authors' own study based on secondary data analyses of employers' survey from "Specific problems of Labour Market in Latvia and its' regions", 2007.

The most uncommon way of looking for employees is the use of personnel selection organizations, inviting qualified specialists from other businesses and using of the services of Employment State agency. The choice of recruitment way is most commonly determined by the resources available to the employer (i.e., size of employees). If the searched employee is of a low qualification and is offered a small wage, it does not pay off to organise a competition.

A wider spectrum of the ways employees searching is more commonly used by larger employers operating with more resources (internet services, transport, knowledge, finances) who are looking for more qualified employees. The recruitment flexibility Index's average value is 0.26 . Table 2 shows the Index structure and values for each element. 
More deepened analysis was carried out to exercise values groups to the Employees Recruitment flexibility Index in rural (including small towns) and urban areas. After the division of the index into four groups and analysing their changes with cross tabulation method, an evident tendency is shrinking of groups with higher values in all areas, except in Riga, where this tendency is not so visible. The Employees' Recruitment Flexibility Index shows differences in variety of used recruitment ways in looking for employees.

This means that only in Riga we can find a considerable part of employers who use various ways of looking for employees and use them „always”. Rural areas are characterised by the greatest differences between employers' with the highest and lowest values of Employees' requirement flexibility index. This means that in rural areas there are more employers who use only one way of employees searching, and fewer employers that use a relatively wide spectrum of ways. The Chi-squared value of $<0.05$ shows statistically important differences in the highest and lowest values of the index in various types of areas (rural and urban).

The differences in the Index values in Riga and rural areas can be explained by Castells theory of global space of flows, as rural areas are in a greater distance from the global flows.

\begin{tabular}{|c|c|c|c|c|}
\hline \multirow{7}{*}{$\begin{array}{r}700 \\
600 \\
500 \\
400 \\
300 \\
200 \\
100 \\
0\end{array}$} & \multicolumn{4}{|c|}{ 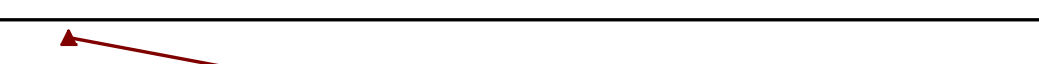 } \\
\hline & \multicolumn{4}{|c|}{-2} \\
\hline & \multirow{2}{*}{\multicolumn{4}{|c|}{ 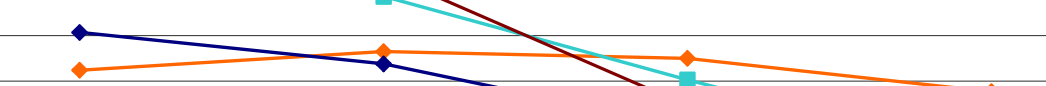 }} \\
\hline & & & & \\
\hline & \multicolumn{4}{|c|}{ 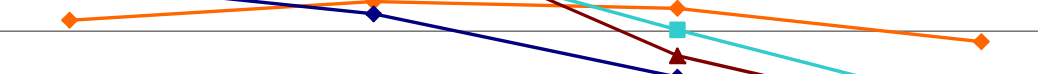 } \\
\hline & \multicolumn{4}{|c|}{$\rightarrow$} \\
\hline & ind12-1 & ind12 2 & ind12 3 & $\begin{array}{l}\text { ind12 } 4 \\
\end{array}$ \\
\hline$\multimap$ Riga & 324 & 365 & 350 & 277 \\
\hline$\rightarrow-$ Major towns & 407 & 338 & 199 & 149 \\
\hline-- Small towns & 565 & 486 & 303 & 132 \\
\hline$\neg$ Rural areas & 661 & 536 & 246 & 93 \\
\hline
\end{tabular}

Fig 2. Employees' Recruitment Flexibility Index in urban (Riga and major towns) and rural including small towns) areas, $N=5431$. Source: the authors' own study based on secondary data analyses of employers' survey from "Specific problems of Labour Market in Latvia and its' regions", 2007.

The employee recruitment flexibility is explicitly lower among employers of rural territories and small towns than among employers of other types of residential areas because advertisements in mass media, the internet and other methods are used less frequently. The lack of the availability of infrastructure resources and insufficient acquisition of ICT may be the reasons for such a low employee recruitment flexibility index among rural employers. Advanced services are unattainable to rural employers due to both - the lack of resources (economical and financial) and the attainability of the adequate infrastructure. Less frequent use of the Internet for employees' recruitment in rural areas could be explained not only as the lack of resources but as well as poor attainability of it. At the same time, it is important to take into consideration the mistrust of the "strangers", unknown employees who are not "one of us". Thus could be described tendency to use more often informal social networks in looking for employees (not need for ICT and possibility to avoid of "strangers"). The mistrust towards strangers as a manifestation of regional spatial differences is described by Bauman (Bauman, 2001), and it is linked with the idea of conservation of community relationships model that is characteristic in rural areas (Wirth, 1938).

That can be explained both by the location of middle size and large enterprises/offices in the urban areas (especially the capital Riga) and by better availability of resources (human, technological, administrative, e.g.). The access to Information Technologies in search for employees and competition processes, as well as the use of personnel search organizations 
are those ways of looking for employees that prevail significantly in Riga in comparison to other areas.

In Riga and its surrounding areas there is also a wider choice of industries and different services (among them advanced) that need highly skilled workers; therefore it is necessary and worth to use a wider spectrum of employee searching mechanisms.

The offer of labour contract forms also characterises differences of the employers' recruitment strategies in urban and rural areas. Survey questions included seven various labour agreement forms offered by employers in different regional units (table 3 ).

\begin{tabular}{|c|c|c|c|c|c|}
\hline & $\frac{\mathbb{O}}{\widetilde{O}}$ & 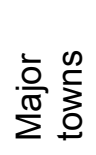 & $\begin{array}{l}\overline{\bar{\sigma}} \\
\stackrel{\infty}{\xi} \\
\dot{\xi}\end{array}$ & 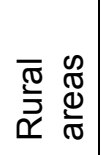 & $x^{2}$ \\
\hline Agreement for indefinite period & 89 & 88 & 90 & 87 & $<0.05$ \\
\hline Agreement for fixed period & 29 & 26 & 26 & 28 & $>0.05$ \\
\hline Agreement of enterprise & 28 & 19 & 22 & 22 & $<0.05$ \\
\hline Agreement for test period & 29 & 29 & 28 & 28 & $>0.05$ \\
\hline Authors' fees & 7 & 3 & 3 & 2 & $<0.05$ \\
\hline Employees work without a written agreement & 1 & 0.5 & 2 & 4 & $<0.05$ \\
\hline Another type of agreement & 2 & 0.5 & 1.2 & 1.2 & $<0.05$ \\
\hline
\end{tabular}

Tab 3. Offer of various labour contract forms in different types of settlement (\%). N= 6066. Source: the authors' own study based on secondary data analyses of employers' survey from 'Specific problems of Labour Market in Latvia and its' regions", 2007.

The values of Chi-square criteria indicates, that regional differences in various types of settlement offering such forms of agreement as the agreement for indefinite period, agreement of enterprise, authors' fees, employee's work without a written agreement, and another types of agreements are statistically valid and show urban/rural division.

Greater differences can be found in using of author's fees and entrepreneur's agreements: they are more often used in Riga, and seldom in other areas.

The statement mentioned by $2 \%$ of employers that „employees are working without any written agreement" has to be regarded as a complete lack of any understanding about the principles of employment law; it shows tradition of ignoring legal demands and has to be considered as a violation of law (the results of other researches indicates much greater, approximately $20 \%$ proportion of usage of unregistered workforce). There are more employers declaring their ignorance to Labour Law norms in rural areas (4\%). According to the opinion of experts of the State Labour Inspection, during the time of economical crisis of 2010 the proportion of unregistered workers has rather increased (Number of jobseekers, CSB, 2011). The diversity of working agreements characterises a potential flexibility in the relations among employers and employees that refers to the external flexibility.

The logic of offering working agreements could be impacted by stability of employer. Absolute majority of employers evaluate the situation of their enterprises/offices as stable now and in future (54\%), 37\% consider the enterprises/offices as stable now; but are not convinced about stability in the future. A part of the respondents draws attention to the difficulties of functioning of the enterprise or even being in the phase of liquidation (7\%). The proportion of enterprises/offices with difficulties of functioning and being in phase of liquidation is higher in rural areas and in major towns; but relatively higher proportion of employers considering themselves as stable now and in future can be found in Riga. That means that employers in rural areas have more difficulties of functioning and are at greater risk of liquidation. The values of Chi-square criteria show, that regional differences in various types of settlement offering such 
forms of agreement as the agreement for indefinite period, agreement of enterprise, authors' fees, employee's works without written agreement, and another types of agreements are statistically valid.

Secondary data of employers' survey were also analyzed by factor analysis, and by finding out statistically significant factors. Combination of statistical analysis methods allows receiving statistically valid results in finding out the differences of regional labour markets. In order to increase generalisation level of the evaluation of flexibility of employer and employee relations, factor analysis was performed. The author of the article used its variation - Principal Components Method. Application of the method allows revealing latent or hidden factors that characterise the employers' understanding about the flexibility of labour market relations. 50 indicators of the possible 53 were included in the factor analysis. The selection was performed, determining the suitability of the indicator to the factor within the weight limits of 0.4 levels in every factor. Initially factor analysis was performed with 15, 14, 13 factors, admitting the 14 factor model as the optimal. Varimax orthogonal factor rotation method was used in the factor analysis.

In the sequence of dispersion reduction it is possible to distinguish the following factors: ethnic tolerance (11.48\% dispersion), professional demands (7.4\% dispersion), Latvian and social and demographic $(4.95 \%$ dispersion), flexible employee recruitment $(4.72 \%$ dispersion), social solidarity (3.67\% dispersion), education and growth (3.57\% dispersion), surplus work time (2.98\% dispersion), marginality $(2.62 \%$ dispersion), bypassing formal requirements $(2.29 \%$ dispersion), sexual minorities and HIV (2.23\% dispersion), retirement (2.23\% dispersion), work security $(2.13 \%$ dispersion), work time flexibility $(1.95 \%$ dispersion) and informal employee recruitment (1.94\% dispersion).

Performing cross-tabulation analysis for factor range groups in regions, five factors in regions differ statistically significantly. They are ethnic tolerance; flexible employee recruitment; marginality; sexual minorities and HIV, and informal employee recruitment factors.

Across the types of residential areas such factors as - ethnic tolerance, Latvian and demographic groups, flexible employee recruitment, education and growth, marginality, sexual minorities, retirement, work time flexibility and informal employee recruitment - differ statistically significantly. Nine factors differ in total.

Factor analysis let to find out nine latent factors which have an impact on the relations between employers and employees in the rural areas, and two of them relate to employees recruitment: factor of flexibility in looking for employees (including various types of finding employees) and factor of informal looking for employees. The factor of flexible finding of employees and factor of informal looking for employees have statistically significantly lower values in rural areas (Employers' survey data, 2007, $\mathrm{N}=6,066$ ).

The conclusion of the analyses is that factor of informal looking for employees, use of informal ways have lower values in rural areas. This is surprising in light of classical urban sociology urban theories (Louis Wirth) and shows peculiarities in the use of social capital in rural areas (Wirth, 1938). Operation of flexible employee recruitment and informal employee recruitment factors can be associated with the junction points of global flows because they mean usage of information technologies and advanced services or the opposite - lack of them. The quantitative analysis of the labour market relations indicates that there are statistically significant differences in the flexibility of labour market relations and the employer representation in different territorial units (Riga, major towns, small towns, rural territories).

Differences in the operation of ethnic tolerance, sexual minorities and HIV factors can be explained by Baumann's fear of the strange.

Thus, while performing the research of the labour market relations, it is important to provide a sample in which respondents of different territorial units are represented in numbers that allow making statistically valid conclusions. The number of employers using various ways to recruit employees and offering them flexible choice for working agreement is extremely low in rural areas. The informal strategy in the search for employees is the dominant tendency. The surprise of results is the prevalence of this strategy in urban areas, too. Flexible usage of 
different ways in looking for the employees and the offer of various contract forms are common among relatively small part of employers in both rural and urban areas; and some forms of contract and ways of looking for employees are almost unknown in rural areas.

Qualitative analysis was performed to specify data about the situation of the labour market in small towns and rural territories. Interviews let to show factors that affect employer and employee relations in a wider context, which is not ensured by the analysis of the survey results. The author has analyzed partly structured profound interviews with public employers (municipality chairpersons) (20) and private employers (40).

Municipality chairpersons shall be considered the labour market agents acting as employers for municipality staff. They are also mediators of the labour market relations, who manage their daily duties at the local level and who have to be interested in enhancing labour market relations (On Local Governments, 2011). Municipality chairpersons emphasize the problems of infrastructure (particularly, roads, transport, and ICT) in rural territories and in small towns. The infrastructure is one of the elements of Castells' global flows theory. Namely, to provide post-industrial labour market relations, the access to global flows is of utmost importance, and it includes infrastructure, information, and access to power hierarchy (i.e., administrative, judicial and legislative power). Several municipality chairpersons emphasise the problem of qualitative vocational education and attracting of qualified labour to rural territories and small towns, which exacerbates problems of the youth employment and the unemployment. Municipality chairpersons emphasize chronically lack of work places for women, pre-retirement age persons and persons with low skills. There is also lack of highly-qualified specialists who could organize interaction between different regional units, economic fields and work with EU funding.

The division of responsibility in economy that has been inherited from the socialistic system of management and is difficult to be changed, lack of integration and coordination between industry monitoring institutions prevent implementation of entrepreneurship supporting strategies.

The strong roots (embeddedness) of municipality chairpersons in local traditions, relation to their kin, and community of relatives can also be explained as cultural peculiarities in rural areas. It can be evaluated both positively and negatively from the perspective of the development and the existence of labour market relations. The local rootedness creates stability and facilitates labour market activities on the local scale. At the same time, the readiness of municipality chairpersons to adapt to the new social and economic situation in the labour market changing the industry of the activities, position and a former career path, indicates the ability to become "path breakers". The author refers to those labour market agents with the notion "path breakers" who, by adapting to the labour market situation in the postsocialistic society, are ready to start a new direction of professional activity and a career path.

Lack of flexibility in labour market relations in particular spatial regional units can be expressed in at least two ways how labour market agents and mediators react to the changes.

1. Traditional operation (according to the previously acquired successful model). It means hoping for production development (sewing and food enterprises, work as tractor drivers in farming, opening manufacturing subsidiaries). Orientations to the previous profession, work conditions, position, labour relations.

2. Leaving the place. It can be done by any of the labour market agents (and it is already done). To emigrate, to transfer the enterprise, to stop offering a particular employment service. It is typical in places with a higher unemployment level, especially long-term unemployment, higher migration (Rasnaca, et al., 2007; Boyd, 2002).

The requirements for the employees of micro, family businesses differ. Employers who are the owners of those micro enterprises that basically operate as family businesses in agriculture emphasise the execution, the readiness to perform different tasks, and the time necessary for carrying out work. These characteristics approve insufficient employability situation in rural territories. Employers who correspond to the small enterprises group according to the number of employees emphasise the importance of appropriate education because the required skills and knowledge cannot be acquired without necessary background knowledge. 
All the interviewed private employers in rural territories and small towns are rather oriented to the local labour force because they assign big importance to recommendations and former behaviour of the employee in the labour market and outside it. Both selection based on the professional experience and similarity, principles of the equals in age group operate in employee recruitment

Private employers emphasise the importance of employee knowledge and qualification, but it is also important to be "one of us", a person with similar age, social contacts, the local. There is lack of trust to cooperate with Employment State agency. Employers describe indisposition to use services of Employment Agency as negative experience with job-seekers registered in agency (for example, discipline problems, addictions among recommended job seekers).

The results are similar to findings by Lyndsay (Lyndsay, 2005) in Scotland's remote rural areas where job seekers using informal networks were more successful finding working place. Current study shows that particular indisposition of employers to use services of Employment State agency emphasises importance of informal networks in successful recruitment result. Interviews with municipality chairpersons and employers as well as quantitative analysis show important, deeply embedded problems of employment in rural areas solving of which need complex cooperation and mutual trust from labour market agents.

\section{Conclusions}

1. The first task of study was to carry out the theoretical analyses of labour market relations. The author's theoretical model includes synthesis of Castells' "space of flows" and Baumans' "non-place" and "strangers' perception". Ideas of these authors can be regarded as conceptually supportive, but not sufficient for explanation of labour market relations disparities between employers and employees in recruitment process. Author explores applicability of labour market flexibility concept.

2. The labour market relations between employers and employees could be analyzed as an expression of flexibility in the labour market relations. The second task was analyses employers' survey data in order to find out regional differences in recruitment of employees.

3. Employee recruitment in different types of residential areas differs statistically significantly. Most frequently employees are recruited through informal channels - recommendations of relatives, friends and acquaintances. Similar results regarding labour market relations in Latvia were obtained also in the previous research. The results of the secondary analysis allow stating that there are statistically significant differences in using methods of employee recruitment in rural areas of Latvia and in Riga and major towns, where various methods most frequently are used. The least frequently used method of employee recruitment in small towns and rural territories is announcing a competition, using services of personnel recruitment companies and placing a job advertisement on the internet. The interviewed employers justify such behaviour with lack of trust in formal criteria and reliance on the validity of personal references. The employee recruitment flexibility is essentially lower among the employers from rural areas (rural territories and small towns) than among the employers in other types of settlement - urban areas. This is due to the fact that the advertisements in mass media, on the internet and other employee search methods are used less frequently.

4. The flexibility of labour market relations is affected by latent factors. Factor analysis let to find out nine latent factors which have an impact on the relations between employers and employees in the rural areas, and two of them relate to employees recruitment: factor of flexibility in looking for employees (including various types of finding employees) and factor of informal looking for employees. The factor of flexible finding of employees and factor of informal looking for employees have statistically significantly lower values in rural areas.

5. The two most popular strategies used in recruitment of employees by the employers are the flexible and the inflexible strategy. The flexible strategy is more popular among urban employers. 
The choice of inflexible strategy rural employers' explain as negative the previous experience, lack of trust and necessity to use informal networks (kind of social capital) as security guaranty. Other forms of social capital are not so popular in the recruitment strategies used by the rural employers.

6. The situation of the labour market in rural areas is affected by the public sector employers' representation, which is actively supported by the municipality chairpersons. Results of the quantitative research indicate to a lower representation of public sector employers in the small towns and rural territories, therefore the existing ones in the local labour market situation are especially important. The qualitative analyses let to indicate the most significant exogenous factors are: quality of roads, availability of health care and education services, quality of education, availability of the internet, availability of public transport, social security system at the national level and opportunities for leisure time activities.

7. Qualitative analyses show explanations of recruitment differences in rural areas and among size groups of employers. Requirements for the employees differ in the small and micro, family enterprises. Employers who are owners of micro, family farm enterprises mainly emphasise execution, readiness to perform different kinds of work and work the required number of hours. These features approve of the insufficient employment situation in the rural territories. Employers who belong to the group of small enterprises and operate in technologically complicated industries (provide progressive services) also emphasise the importance of appropriate education because the required skills and knowledge cannot be acquired without the necessary background.

\section{References}

[1] Akiyoshi, M. (2003). Flexibility of Communication, University of Chicago. Retrieved: http://www.allacademic.com//meta/p_mla_apa_research_citation/1/0/6/5/7/pages106570/p 106570-php. Acesss: 21072011.

[2] Amin, A. \& Thrift N. (1995). Globalisation, Institutional "Hickness” and the Local Economy. In P. Healey, Cameron, S., Grahm, S. \& Madani-Pour, A., Eds., Managing Cities: the New Urban Context (pp. 91-108). Chichester: John Wiley.

[3] Bauman, Z. (2001). Liquid Modernity. Cambridge: Polity Press.

[4] Boyd R. (2002). A „Migration of Despair”: Unemployment, the Search for Work, and Migration to Farms during the Great Depression. Social Science Quarterly, 83(2), 554-567. Doi: 10.1111/1540-6237.00100.

[5] Bradley, H., Erickson, M., Stephenson, C. \& Williams, S. (2000). Myths at work. Cambridge: Polity Press.

[6] Bird, K., Hulme, D., Moore, K., Shepherd, A. (2003). Chronic Poverty and Remote Rural Area, CPRC Working Papers 13. University of Birmingham / University of Manchester.

[7] Bromley, D. (1989). Economic Interests and Institutions. New York: Basil Blackwell.

[8] Castells, M. (2000). The Rise of the Network Society. Oxford: Blackwell Publishing.

[9] Copus, A., Hall C., Barnes, A. (2006). Study on Employment in Rural Areas (SERA). Brussel: European Commission, Directorate General for Agriculture.

[10] Douglas, C. (1990). Institutions, Institutional Change and Economy of Institutions. Cambridge University Press.

[11] Edgell, S. (2006). The Sociology of Work. London: Sage Publications.

[12] EU statistics (2011). Central Statistics Bureau.

[13] Ghezzi S. \& Mingione E. (2007). Embeddedness, Path-dependency and Social Institutions. Current Sociology, 55(1), 11-23. Doi: 10.1177/0011392107070131. 
[14] Gottdiener M. \& Hutchinson R. (2006). The New Urban Sociology. Boulder: Westview Press.

[15] Gouliquer, L. (2000). Pandora's Box: The Paradox of Flexibility in Today's Workplace, Current Sociology 48(1), 29-38. Doi: 10.1177/0011392100048001004.

[16] Handel, M. (2003). Complex Picture of Information Technology and Employment Emerges. Arlington: SRI International.

[17] Hodge, I., Dunn, S. \& Fitzgerald, M. (2002). Barriers to participation in residual rural labour markets. Work, Employment and Society 16(3), 457-476. Doi: 10.1177/095001702762217434.

[18] Kalleberg, A. \& Sorensen, A., (1979). The Sociology of Labour Markets, Annual Review of Sociology, 5, 351-379.

[19] Kostiainen J., Sotarauta, M. (2003). Great Leap or Long March to Knowledge Economy: Institutions, Actors and Resources in the Development of Tampere, Finland. European Planning Studies 11(4), 415-438. Doi: 10.1080/09654310303648.

[20] Lamote, B. \& Zubirirey, J. (2008). New forms of Labour Market segmentation, insecurity and professional relations, International Working Party on Labour Market Segmentation, $29^{\text {th }}$ annual conference. Retrieved: http://halshs.archives-ouvertes.fr/docs/ 00/34/05/90/DOC/pub08020.doc. Access: 4112011.

[21] Latvijas un tās reǵionu darba tirgus specifiskās problēmas (2007). Eiropas Savienības struktūrfondu nacionālās programmas „Darba tirgus pētījumi” projekts "Labklājības ministrijas pētījumi”. LLU, DU, RSU, Ve A, VA. Jelgava: Jelgavas tipogrāfija.

[22] Lindsay, C., McCracken, M. \& McQuaid, R. (2003) Unemployment duration and employability in remote labour markets. Journal of Rural Studies 19(2), 187-200. Doi: 10.1016/S0743-0167(02)00067-0.

[23] Majerová V. (2009). Czech Republic: Regional Disparities and their Influence on Sustainable Rural Development. In Bruckmeir K. \& Tovey H., eds., Rural Sustainable Development in the Knowledge Society (pp. 77-94). Farnham: Ashgate Publishing.

[24] Marsden T. \& Smith E. (2005). Ecological Entrepreneurship: Sustainable Development in Local Communities through Quality Food Production and Local Branding. Geoforum 36(4), 440-451. Doi: 10.1016/j.geoforum.2004.07.008.

[25] Number of inhabitants (2010). In Latvian: Patstāvīgo iedzīvotāju skaits. Riga: Central Statistic Bureau Latvia.

[26] Number of jobseekers. (2010). In Latvian: Patstāvīgo iedzīvotāju skaits. Riga: Central Statistic Bureau Latvia.

[27] On Local Governments (1994). Law of Latvia Republic (In Latvian: Par pašvaldībām.: LR likums).

[28] Rasnaca L. (2010). Darba devēju un darba ņēmēju attiecību reǵionālo atšķirību pētniecība Latvijā 21.gadsimtā Gr.: T.Tisenkopfs (sast. un zin.red.) Socioloǵija Latvijā. (pp. 239-254). Rīga: LU Akademiskais apgāds.

[29] Rasnaca, L, Kruzmetra, Z. \& Bite D. (2007). Changes in the Towns and Countryside of Latvia after Accession to the European Union. In: Uncertain transformations - new domestic and international challenges, Proceedings of the International Conference (pp. 343-357). Riga, November 9-11, LU.

[30] Strangelman, T. \& Warren, T. (2008). Work and Society. London: Routledge.

[31] Streeck, W. (2005). The Sociology of Labour Markets and Trade Unions, In Smelser, N. J. \& Swedberg, R., eds., The Handbook of Economic Sociology, $2^{\text {nd }}$ ed. (pp. 254-283). Princeton: Princeton University Press. 
[32] Swedberg, R. (2005). Markets as social structures, In Smelser, N. J. \& Swedberg, R., eds., The Handbook of Economic Sociology, $2^{\text {nd }}$ ed. (pp. 238-253). Princeton: Princeton University Press.

[33] vander Steene T., Sels L., van Hootegem G., de Witte, H. \& Forrier A., (2002). The Impact of the Institutional Context on the Politics of Flexibility: Comparison Belgium-the Netherlands. Journal of European Industrial Training, 26(8), 384-393. Doi: 10.1108/03090590210444964.

[34] Wirth, L. (1938). Urbanism as a Way of Life. The American Journal of Sociology 44(1), 1-4.

[35] Zobena, A. et al. (2007). Latvia. Human Development Report 2006/2007. Riga: Latvijas Universitate. 